\title{
THE BICENTENARY OF COLUMBIA UNIVERSITY
}

\author{
By Prof. L. C. DUNN \\ Professor of Zoology, Columbia University
}

$\mathrm{T}$ HROUGHOUT the year 1954 there is being celebrated both in New York and at other centres of learning the two hundredth anniversary of the founding of Columbia University. The theme of the extensive series of symposia, conferences, lectures, exhibits and meetings of learned and civic societies is "Man's Right to Knowledge and the Free Use thereof", intended to illustrate not only the growth of knowledge but also its employment in the maintenance of free popular institutions.

Columbia University itself is an example of such an institution. King George II granted its charter as King's College in October 1754. It later became Columbia College, and at the turn of the twentieth century, at the time when, by union of the boroughs, New York City assumed its present metropolitan structure, the College and its affiliated schools assumed the style "Columbia University in the City of New York", emphasizing what has remained true from the beginning, namely, the intimate connexion between the self-supporting and independent university and the eivic centre.

The aims of the College were set forth by its first president, the American scholar, Dr. Samuel Johnson (no kin to the lexicographer), in an advertisement published in New York, May 31, 1754 : “. . . to instruct and perfect the Youth in the learned Languages, and in the Arts of reasoning exactly, of writing correctly, and speaking eloquently; and in the Arts of numbering and measuring; of Surveying and Navigation, of Geography and History, of Husbandry, Commerce, and Government, and in the Knowledge of all Nature in the Heavens above us, and in the Air, Water and Earth around us, and the various kinds of Meteors, Stones, Mines and Minerals, Plants, and Animals, and of every Thing useful for the Comfort, the Convenience and Elegance of Life, in the Chief Manufactures relating to any of these Things : And, finally, to lead them from the Study of Nature to the Knowledge of themselves, and of the God of Nature, and their Duty to Him, them. selves, and one another, and every Thing that can contribute to their true Happiness, both here and hereafter...".

This statement makes it evident in what measure the College is derived from the same heady stream of confident benevolence which produced the Declarations of Independence and of the Rights of Man, and the American Constitution. Its large endeavour began in a very small way, in one room and with eight students; but soon it had a building of its own (near what is now Wall Street) ; a medical faculty was added in 1767, and gradually and slowly during its first century, other fields of learning. As it grew it moved progressively northward on Manhattan Island. In mid-nineteenth century it was in rural surroundings at 49 th Street. Its botanical and pharmaceutical garden near by eventually furnished more than herbs, for on that spot now stand the skyscrapers of Rockefeller Center, and from the ground-rent of the garden the University derives a substantial part of its income. In 1897 the present
University Center at Morningside Heights in upper Manhattan (114th to 120th Street) began to be occupied, and in 1928 there was erected the great aggregation of hospitals and laboratories, the Columbia Medical Center at 168th Street, in the centre of which is the Faculty of Medicine, which keeps its traditional name, the College of Physicians and Surgeons.

The most recent changes in the University were occasioned by the Second World War, when it became for a time the centre of research which led to the development of the atom bomb, and was the home of the Midshipmen's School from which 21,150 naval officers received their commissions during 1942-45. The expansion in staff and plant occasioned by these activities has now receded, leaving as permanent addition only the great cyclotron at Nevis, the University estate on the Hudson north of the city.

The form and extent of the University to-day-a federation of 'some twenty faculties and schools-are largely due to Dr. Nicholas Murray Butler, who was its president from 1902 until 1945. This vigorous philosopher, educator and public man gave twentiethcentury actuality to the grandiose hopes of the enlightenment, by bringing together the men and women, who composed what he referred to as $a_{a}$ Community of Scholars, the facilities, in the form of libraries, laboratories, and collections, and third, the material support which was needed. This forceful and, as some thought, domineering man found a way of leaving these ingredients free to make their own adjustments by which productive scholarship could be achieved in the midst of a busy modern city.

The diverse assembly of activities which appeared first at Columbia as part of a university enterprise were referred to by one of his more conservative contemporaries as "Dr. Butler's department store"; but, in fact, these innovations had begun before Butler's time. The School of Mines (first of its kind), which became the School of Engineering, dates from 1864 ; the School of Social Work, now a faculty of the University, celebrated its first half-century in 1948 ; the School of Library Service was founded during the 1880's by Melvil Dewey, father of the Dewey Decimal Classification, and immediately received women students-another shocking innovation. The non-professional graduate faculties of political science, philosophy and pure science, devoted to research and preparation of students for the doctor's degree, appeared in the 1880's and 1890's; while the usual activities of a university in arts, law and medicine had been present almost from the beginning. Teachers College, as a professional faculty of education, has been the centre of controversy since its first incorporation within the University under Dr. Butler, especially as there grew up within it workshops. based on such radical ideas as those of John Dewey (progressive education). Those faculties which have a more modern sound-business, journalism, general studies (for adults)-now seem normal components with architecture, international affairs, dramatic arts, painting and sculpture, pharmacy and the others. 
Dr. Butler's idea was that of a popular university where instruction of all kinds should be available to all who were prepared to receive it, always of course upon payment of a proper fee, since the University had no income from State, city or nation, and its endowment was never great enough to pay more than a part of the costs of instruction and research. Viewed from the outside, it did indeed appear a peculiar patchwork of different intellectual intensities -and Abraham Flexner, in "Universities, American, English, German", pointed out with telling sarcasm some of the contradictions and absurdities which developed within it. This never seemed to trouble Dr. Butler, probably because of his confidence in the attachment of the scholars at the heart of the enterprise to the controlling purpose of the University, that is, the advancement of knowledge and the training of students for independent intellectual activities and practice in the learned professions. Thousands of such students each year thronged its crowded corridors (some 25,000 per year), nearly all for graduate or professional training, for the original College foundation was restricted to a relatively small and select group of young men, now numbering about 2,200. The undergraduate college for women, Barnard College, now in its seventy-fifth year, is also small-about eleven hundred. Most of the university students come from other American colleges, and there are always more from other countries $(1,600$ this year) than in any other American university.

The history of Columbia does indeed show that sound learning based on research under conditions of freedom (that have in general been well maintained) can live and grow within the same environment which fosters popular teaching and applied work of all sorts of science, engineering, industry, education, and public service.

The scientific facilities of the University have always been modest, yet much useful work has issued from it. A typical figure from earlier days was Samuel Latham Mitchill, professor 1790-1801, physician, chemist, anthropologist, geologist and politician, of whose many contributions those are best remembered which engendered the violent controversy that led to the science of sanitary chemistry or engineering. In 1797 he established the first medical journal in the United States and edited it for twenty-three years. In the same tradition was James Renwick, professor of natural and experimental philosophy and chemistry, 1820-53, who wrote much on chemistry and geology but was chiefly distinguished as an engineer, an authority on railroads and canals. His inclined-plane canal lift is still in use on some British and French canals. Later came Charles Frederick Chandler, professor and dean, 1864-1910, a pioneer in public health; Michael Pupin, who began his productive and inventive work soon after he had graduated in 1883 , inventor of the Pupin coil which made long-distance telephony possible, discoverer of secondary $\mathrm{X}$-ray radiation; Leo Baekeland, responsible for 'Velox' photographic paper and for 'Bakelite'. For more recent work Nobel prizes were awarded to H. C. Urey, professor of chemistry (1928-45), for his discovery of deuterium; to I. I. Rabi, professor of physics, for research in the resonance method of registering the magnetic moments of atomic particles; to Enrico Fermi, professor of physics (1939-45), for work in atomic physics; to Hideki Yukawa, professor of physics 1949-54, for his earlier work on development of the meson theory.
One biological field which was given its modern form at Columbia is genetics. T. H. Morgan, professor of experimental zoology (1904-28, Nobel Prize 1933), together with his 'team' (A. H. Sturtevant, H. J. Muller, who received the Nobel Prize in 1946, C. B. Bridges and others) in a brilliant series of experimental analyses of heredity in Drosophila, carried out chiefly between 1910 and 1920, proved the chromosome theory of heredity and laid the basis of the modern theory of the gene. An important part of the foundation for this work was laid by Morgan's colleague in the Department of Zoology, Prof. E. B. Wilson, whose own classical investigations in cytology found lasting influence in his book, "The Cell in Development and Heredity", first issued in 1896, and now (in its third and final edition of 1928) recognized as one of the seminal books of modern biology.

Among other Columbia names in biology and medical research have been Selig Hecht, the physiologist, distinguished for his analysis of the visual process ; Rudolf Schoenheimer, the biological chemist, whose book "The Dynamic State of the Body Constituents", itself marking a turning-point in the study of metabolism, showed how close he was, at his early death in 1941, by virtue of ideas gained from the use of isotopes, to new insight into the structure and reproduction of living matter; Hans Zinsser, bacteriologist (typhus fever) and writer; and many eminent men now living, and hence not mentioned here.

A unique chapter in scientific history at Columbia opened in 1939 and is described in the following excerpt from the report of the acting president, Frank D. Fackenthal, for 1945: "As is now well known, the atom bomb was the logical result of a discovery by Otto Hahn and F. Strassman of Berlin that some chemical elements of about half the atomic weight of uranium were present after exposing to neutrons specimens of pure uranium compounds which were previously free from any of these lighter elements. From this, Hahn, in an article published early in January 1939, reasoned that the nuclei of some of the uranium atoms had suffered splitting or 'fission' on picking up neutrons. Neils Bohr, of Copenhagen, arriving at Princeton, January 16, 1939, brought the news of Hahn's discovery and also the suggestion of Lisa Meitner and $O$. R. Frisch that the fission of an atom of uranium must be a very violent action liberating a large amount of energy. Prof. Rabi and Dr. Lamb, of our Department of Physies, brought the word from Bohr to Columbia, where it was seen at once that neutrons must be thrown off in the fission of a uranium atom, that these neutrons would cause other atoms of uranium to split and that thus a chain reaction could proceed with great rapidity and an enormous release of energy. In a fow hours Prof. Fermi was estimating how large a part of Manhattan Island could be blown up by a few pounds of uranium properly disposed. As a result of discussions among Profs. Fermi, Dunning, Rabi, Pegram, Urey and others of our staff, experimental demonstration of the large amount of energy liberated by the fission of an atom of uranium was sought. In the experiment planned by Dunning and Fermi and carried out by Dunning on January 25, 1939, unmistakable evidence of the violence of the fission was found, the evidence appearing as relatively enormous pulses of ionization. Later it was learned that Frisch in Copenhagen had made the same demonstration ten days earlier. From that time 
until now, the larger part of the work of Columbia's physicists and of numerous members of other departments has been devoted to the problems of nuclear fission and the release of atomic energy".

The "Manhattan Project", so-called, was centred at Columbia during 1939-45, utilizing much of the scientific space of the University and, with its scientific staff of 250 and 1,200 others, overflowing into other buildings in the neighbourhood. The work with the uranium-graphite pile was shifted to Chicago in 1942, and the chief effort at Columbia was devoted to the gaseous diffusion method of separating uranium-235.

The chief contributions of Columbia University, however, have been in fields other than science, which was a relatively late development. Great lawyers, judges, and legal scholars have issued in continuous line throughout its history-the two Roosevelt presidents coming from its law school, as also three chief justices and many associate justices ; statesmen-from Alexander Hamilton, John Jay, DeWitt Clinton (the governor of New York who built the Erie Canal) - to the present governor. It was from Columbia that F. D. Roosevelt drew his 'brain trust' of 1932; his rival for the Democratic nomination in that year is said to have poached on Roosevelt's preserves, and the two candidates gave forth with one speech written impartially for both by the same Columbia 'ghost'. The Faculty of Political Science has had a long and honourable history, but it must be told by one who knows. In philosophy one thinks of John Dewey, who spent fifty active, even turbulent, years at the University; in anthropology, of Franz Boas, who between 1893 and 1940 was responsible not only for the creation of a school of linguistics but also put his stamp on the whole of American anthropology, both social and physical.

But it would be idle for one who is not a historian, nor capable of judgment outside of the restricted field of his own experience in science, to choose more persons or events for emphasis from an array extending over two hundred years.

I write from Rome, a distance of half the globe away, and after nearly a year's absence from that University. In the United States it seems like a European university, in the independence of its faculties and schools and departments, its avoidance of prescription or undue interference with the lives of its students and professors, the absence of indoctrination, conformalization, 'college spirit'. Looked at from Europe, however, one readily perceives an American look-a fluidity and responsiveness to the times that is less clearly seen in the older European foundations that depend on the State. In the past this fluidity was made possible by the University's freedom to dispose of its own income from endowment as it saw fit. With the new increase in cost and the decrease in income from investments, this freedom is now restricted. New things can still be done in such an American university, in part because resources from the great philanthropic foundations can be placed quickly at the disposal of persons with new ideas. Fortunately, this is now not restricted to American universities but is increasingly shared by learned institutions elsewhere. This, and the increasing participation of government and of industry in support of research through contractual arrangements, will surely profoundly affect the future of Columbia as of other universities.

\section{AGRICULTURAL EDUCATION IN GREAT BRITAIN}

GOR any adequate appreciation of the recent Report of the Working Party on Agricultural Education* some knowledge of the changes that have taken place during the past fifteen years is essential. Prior to the Second World War, agricultural education and advice to those engaged in any branch of the agricultural industry constituted $a$ single service maintained by local government bodies-usually county councils-but financed mainly by the Ministry of Agriculture, not the Ministry of Education. A fraction of the cost was borne by the rates. The committee of the county council controlling the service was, as a rule, the Agriculture Committee, which often delegated this particular section of its work to an Agricultural Education Sub-Committee. In the dozen or so counties where an agricultural institute existed, this was normally controlled by the same body or a further sub-committee.

The chief officer of the county council responsible for the service was the agricultural organizer of agricultural education and, with rare exceptions, every county council had such an officer. His status in the hierarchy of county officials was high, often with the right of direct access to the clerk of the county council. Owing to the comparatively small number of agricultural organizers, it was also easy for them to have, unofficially, personal contacts with senior officials of the Ministry of Agriculture in London, which also maintained a small inspectorate. The whole set-up was a loose one-typically British -which worked brilliantly or dismally, depending on the county personnel-the officials appointed and the members of the Agricultural Education Subcommittee.

In some counties, a very fine system of agricultural education had been built up, with day and evening classes in various centres covering practically all the branches of agriculture and horticulture found within the county. The organizer, in addition, had his tasks of giving advice to farmers and other growers, visiting farms when necessary to take samples of soil, milk, feeding stuffs, etc. Also, he conducted demonstrations and experiments of various kinds on commercial farms, for example, on the manuring of grass or other crops, the feeding of livestock, comparison of varieties and the use of weed-killers.

A loose link-up between counties was provided by the provincial centre, situated at a university or agricultural college, as, for example, at the School of Agriculture, Cambridge, for the eastern counties. At the provincial centre there were specialists in chemistry, entomology, etc., on whose services the county organizer could call for the solution of problems which he could not solve himself. Quarterly meetings of the organizers and one or more members of their staffs, held at the provincial centre, provided occasions for the discussion of common problems, the drafting of co-operative experiments and numerous other matters. On the whole, the pre-War system of agricultural education in the counties was a happy one which, moreover, was capable of rapid development by taking the forward counties as a model and spurring on any laggard to approach the same level of achievement.

* Ministry of Agriculture and Fisheries. Report of the Working Party on Agricultural Education. Pp. 20 . (London: H.M. Stationery
Office, 1953.) 9d. net. 